\title{
6 \\ JIHADI MILITANCY AND HOUTHI INSURGENCY IN YEMEN
}

\author{
Elisabeth Kendall
}

Yemen has long been plagued by conflict. The main fault line is between northern and southern Yemen, which were separate countries before they signed an awkward union in 1990. Within four years, they were already at war, and tensions remain high to the present day. Numerous other divides exist, which tend to fall along tribal lines. Tribal leaders, laws, and customs continue to occupy important positions in Yemeni society, exacerbated by the lack of strong state institutions. Former Yemeni President Ali Abdullah Saleh famously likened dealing with Yemen's tribal elites to dancing on the heads of snakes. ${ }^{1}$

Politicians are not alone in exploiting Yemen's fault lines. Yemen's main terrorist group, al-Qaida in the Arabian Peninsula (AQAP), has tried to frame north-south tensions as a holy war between Sunnis (southerners) and Shia (northerners). Yemen attracts terrorists in a number of ways. Its topography of deserts, mountains, and wadis (valleys) makes it easy to lie low and engage in paramilitary training. Moreover, its civil war chaos, government exodus, disillusioned population, and critical humanitarian crisis make it a rich recruitment ground for vulnerable and angry young men.

This chapter provides an overview of Yemen's modern history, which is necessary to understand the origins of today's conflicts. It then explains the emergence and development of AQAP and the Islamic State in Yemen, assessing their respective goals and strategies and the extent of their success. Finally, it examines how the Houthi insurgency managed to take over the reins of government and overrun much of the country in 2014.

\section{Overview: the modern history of Yemen}

A brief background of Yemen is essential for contextualizing the conflicts and power struggles shaping the country today. The contemporary unrest that erupted into all-out civil war in 2015 was neither new nor binary. It was the product of a complex web of conflicts rooted in history and exacerbated by clashing local, regional, and international agendas.

In the centuries preceding unification in 1990, Yemen was a loose patchwork of different sheikhdoms, sultanates, emirates, and an imamate ${ }^{2}$ in the north that at times expanded into the south and east. Yemen was technically part of the Ottoman Empire until 1918, although the Ottomans only exercised weak control over this mass of disparate rulers scattered across distant and difficult terrain.

In 1839, the British quickly seized the southern port of Aden, developing it into a trading colony where its importance gradually increased, boosted by the opening of the Suez Canal in 1869. The British struck 
alliances with the various sultans, sheikhs, and amirs (leaders) who controlled Aden's tribal hinterlands and also extended British influence further east toward Oman.

The result was that large areas of Yemen's south and east became British protectorates, while the northwest of the country continued to be ruled separately as an imamate, as had been the case since the late 9th century with some ebb and flow. Yemen's north-south divide was always problematic. The north never fully accepted the dividing line drawn in 1904 by the Ottomans and British. ${ }^{3}$

Profound changes occurred in both the north and the south during the 1960s with the emergence of nationalist sentiment fueled by simmering resentment and deep-seated grievances. Power struggles ensued. In the north, the imamate was toppled in 1962 and the Yemen Arab Republic proclaimed in its place. A civil war followed in which regional powers became entangled. Egyptian President Gamal Abd al-Nasser dispatched thousands of Egyptian soldiers to Yemen to bolster the nascent republic in line with blossoming pan-Arab nationalist sentiment. On the other side, Saudi Arabia, Jordan, and the British helped those who wanted to reinstate the imamate. ${ }^{4}$

It was only in 1967 that Egypt finally withdrew its struggling forces from Yemen, having suffered a crippling defeat closer to home in the Six-Day War against Israel. By 1968, Saudi Arabia agreed to recognize the Yemen Arab Republic in the north, and a governing council formed in Sanaa. Egypt's costly and disastrous military experience in Yemen in the 1960s may have contributed toward its decision not to contribute troops to the Saudi-led coalition's intervention in Yemen in 2015.

In southern Yemen, meanwhile, Britain attempted to secure its interests in the face of growing turbulence by establishing the Federation of South Arabia in 1959. It was unable to rein in the growing wave of nationalist sentiments, which the Egyptians had taken the opportunity to stoke in the south. A series of violent independence movements finally led the British to withdraw from Yemen entirely in 1967. That same year, the National Liberation Front swept to power and formed the People's Republic of South Yemen.

South Yemen became the People's Democratic Republic of Yemen in 1970. But not all southern regions were integrated willingly into the new southern state, ${ }^{5}$ which was the Arab world's first and only Marxist regime. ${ }^{6}$ Following the untimely British withdrawal, ${ }^{7}$ and with it any hope of protection, dissenters were either crushed or fled to neighboring Gulf countries. There was also a mass exodus of southerners to Yemen's north, a shift that was to exacerbate north-south tensions in coming decades.

Years of political turbulence ensued. Clashes erupted along the north and south border several times in the 1970s, most seriously in 1979 with a two-month war. A military coup in 1974 allowed the north to consolidate power into a command council dominated by the military. Power struggles persisted, and two council chairs were assassinated in quick succession before Ali Abdullah Saleh took over in 1978. Through a mixture of carrot and stick tactics, ranging from harsh repression to generous patronage, coupled with blatant nepotism, particularly in the military and security sectors, Saleh was able to remain in power for more than three decades. ${ }^{8}$

During the 1980s, as Saleh consolidated his power in the north, the socialist south was sharply divided, with competing political factions jockeying for control. The power struggles erupted into armed conflict in 1986 known as the South Yemen Civil War. With the economy in ruins and Moscow's support receding as the Soviet Union disintegrated, the southern People's Democratic Republic of Yemen eventually united with the north in 1990. Saleh became president of the United Republic of Yemen. Significantly, however, the northern and southern militaries were never merged, and simmering disputes over the allocation of power and resources were never resolved. ${ }^{9}$

Just four years later, in 1994, the pro-union north and the socialist separatist south were again at war. Although the hostilities ended after two months with a victor's peace for the north, the repercussions can still be felt today. After the war, the military personnel of the former southern Yemeni state were demobilized and deprived of their pensions. Many of them became activists who formed the backbone of the southern secessionist movement that coalesced in 2007. 
The movement, known as the Hirak, won widespread support among a population seething with resentment against the north, which it accused of monopolizing political power, seizing land, and exploiting southern resources. It was also during the 1994 war that Saleh mobilized jihadis to help him fight the southerners, whom he framed as godless socialists. Usama bin Ladin gave Yemeni members of al-Qaida permission to rush home to join the war. ${ }^{10}$

As a result of this historical legacy, Yemen's “Arab Spring” in 2011 was not simply an opportunistic uprising inspired by the popular unrest in Tunisia and Egypt. Rather, it was the crescendo of widespread tensions that had been gathering steam for years. ${ }^{11}$ Popular grievances included corruption, nepotism, preferential patronage, economic underdevelopment, political marginalization, collaboration with the controversial U.S. drone program, and an unpopular and blatantly undemocratic succession plan by which Saleh's son, Ahmad, would inherit power. ${ }^{12}$

When Yemeni security forces fired live rounds on crowds of protestors on March 18, 2011, Saleh's regime broke into factions, and the Yemeni army fractured. ${ }^{13}$ Saleh was deserted by powerful figures, including Army General Ali Muhsin al-Ahmar. ${ }^{14}$ In 2016, al-Ahmar would become vice president and commander of the armed forces fighting against Saleh.

A Gulf Cooperation Council transition plan arranged for Saleh to be replaced. Although Saleh eventually agreed, there were significant flaws in the plan. ${ }^{15}$ Not only was the new president, Abdu Rabbu Mansour Hadi, Saleh's direct deputy, but he was also the sole candidate permitted to stand in the February 2012 elections. Moreover, transitional justice was entirely absent. Saleh was kept on as head of the ruling party and granted immunity from prosecution. Crucially, this gave him a free hand to pursue spoiler activities. Meanwhile, Hadi's largely cosmetic attempts at military reform left Saleh in a strong position of military influence. This was a key factor in facilitating the Houthi power grab in 2014.

Yemen proceeded to unravel after the Houthis took over Sanaa in 2014 and began to march south the following year. President Hadi fled in March 2015, prompting Saudi Arabia to intervene, leading an alliance of Sunni Arab states. ${ }^{16}$ Saudi Arabia declared three main war aims: contain Iran, restore the Hadi government, and prevent Yemen from fragmenting. Since launching its bombing campaign, Saudi Arabia has failed in all three aims and in all likelihood exacerbated the very situation it sought to defuse. The Houthis, who are part of the Zaydi sect of Shia Islam, have become more dependent on Iran and have increasingly employed more sophisticated weaponry of Iranian origin. ${ }^{17}$

Following the 2019 Riyadh agreement between the Hadi government and the separatist Southern Transitional Council, a new power-sharing cabinet relocated from Riyadh to Aden in late 2020. This arrangement remains fragile. Meanwhile, the Houthis' Supreme Political Council continues to govern most of North Yemen from Sanaa.

"Counterterrorism" remains a convenient justification for all sides in their ongoing battles. The Hadi government characterizes the Houthis as Iran-sponsored terrorists, while the Houthis frame their expansion into central Yemen as a counterterrorism campaign. The Southern Transitional Council justifies its use of force against government forces-including a devastating aerial bombardment by the United Arab Emirates in August $2019^{18}$ — as counterterrorism on the basis of the government's close links to the Islamist Islah Party.

Despite agreements signed by the Hadi government with the Houthis in Stockholm in 2018 and with the Southern Transitional Council in Riyadh in 2019, cease-fires continue to be broken, and peace remains elusive. Meanwhile, numerous other armed groups and tribal militias patrol their own pockets of Yemen in a complex web of shifting loyalties. In short, Yemen is fragmenting.

\section{The emergence of AQAP}

Militant jihad in Yemen, as elsewhere in the Middle East, was fueled by war and civil unrest. President Saleh forged pragmatic ties with radical clerics in the 1980s and 1990s to enlist Islamist extremists for his 
ongoing power struggle with the south. The continuing dominance of Marxist ideology among southern political elites made them easy to frame as godless infidels in an obvious parallel to Usama bin Ladin's jihad against the Red Army in Afghanistan throughout the 1980s. ${ }^{19}$

As the 1994 civil war brewed, Tariq al-Fadhli, a leading southern tribal figure who had fought with al-Qaida in Afghanistan, was promoted to colonel in the Yemeni army and sent to rally his men in Abyan, a coastal governorate northeast of Aden. ${ }^{20}$

Yemen's civil war in 1994 also coincided with growing intolerance toward Arab jihadi fighters in Afghanistan both by local warlords and the neighboring Pakistani government, as well as a crackdown on Ayman al-Zawahiri's Islamic Jihad group in Egypt. Yemen-with its civil strife, low cost of living, and ungoverned spaces - seemed like an ideal place for them to regroup and train. ${ }^{21}$ Al-Zawahiri himself reportedly relocated to Yemen for a year in 1994, joining his brother Muhammad and other Egyptian jihadis who had already relocated there. ${ }^{22}$

In the mid-1990s, a militant jihadi group known as the Aden-Abyan Islamic Army formed in south Yemen under the leadership of a local veteran of the Afghan jihad, Zayn al-Abidin al-Mihdar. The group operated with support from a high-ranking military commander, Ali Muhsin al-Ahmar, who had married Fadhli's sister. ${ }^{23}$ Ali Muhsin would later become Yemen's vice president and commander of the armed forces in 2016. This history is relevant because it lends credence to reports of informal alliances between AQAP and parts of the Saudi-backed Yemeni military during the current war. ${ }^{24}$ Indeed, by 2016, the United Arab Emirates felt compelled to recruit new, separate fighting forces in key southern governorates to help shift the focus in those areas back to counterterrorism.

The Aden-Abyan Islamic Army began releasing statements in 1998, specifically criticizing increased Western influence on the Arabian Peninsula. In 1998, it kidnapped 16 Western tourists, four of whom were killed in a clumsy rescue operation. ${ }^{25}$ The incident led to al-Mihdar's execution and the end of the group, in theory at least. In practice, the group was subsequently linked to several al-Qaida attacks. The most notable of these were the attempted attack on the USS The Sullivans in 2000, the suicide boat bombing of the USS Cole in 2000 in which 17 U.S. sailors were killed, and the suicide boat attack on the French oil tanker MV Limburg in 2002.

Since 2000, jihadi militancy in Yemen has been dominated by al-Qaida. Anger over the U.S.-led invasion of Iraq in 2003 contributed to its growth. This coincided with the release of many jihadis from jail in the early 2000s to attend a poorly conceived re-education program that prisoners treated more like an exit strategy. ${ }^{26}$ Those who remained in jail-including future AQAP leaders Nasir al-Wuhayshi and Qasim alRaymi-exploited their captivity to recruit fellow prisoners and build a strong jihadi network.

Saleh cracked down on Yemenis attempting to travel to Iraq or neighboring countries without formal government permission. This may have mollified the Americans, but it created longer-term problems in Yemen. Once locked up in Yemen, these thwarted fighters were easy recruitment targets for the jihadi networks forming in prisons. ${ }^{27}$ On the surface, al-Qaida in Yemen appeared to be dwindling in numbers in the early to mid-2000s, but behind locked doors, it was growing. Meanwhile, the international focus on combating al-Qaida had shifted to Iraq and Saudi Arabia.

The international community was caught off guard when al-Qaida in Yemen dramatically resurged following a major jailbreak in 2006 in which 23 jihadis escaped from a high-security prison in Sanaa. ${ }^{28}$ Among the escapees were al-Wuhayshi and al-Raymi, both of whom would in turn become overall leader of al-Qaida in Yemen.

Al-Wuhayshi was the immediate choice, owing to his origin, schooling, charisma, and experience. Born in Abyan, he had the local touch with regard to tribal interaction and recruitment. His religious grounding was strong, as he had graduated from one of the hundreds of religious institutes that had sprung up in Yemen in the 1970s and 1980s. ${ }^{29}$ Moreover, as a veteran of the Afghan jihad, where he had acted as Bin Ladin's personal secretary, he had clear credibility and experience. ${ }^{30}$ 
The jailbreak proved a watershed moment for al-Qaida. Several high-profile attacks followed that demonstrated a step change in technical expertise and coordination. These included a suicide bomb attack on a Spanish tour group that killed 10 people in 2007 and an audacious double car bombing against the U.S. Embassy in 2008 that killed 20, including six attackers. ${ }^{31}$

Al-Qaida in Yemen also benefited from the crackdown on Islamist extremism inside Saudi Arabia. Saudi jihadis fled across the border into Yemen. In January 2009, the Saudi and Yemeni branches of al-Qaida merged to form AQAP. Attacks continued apace, focusing on both Yemeni military and international targets, such as the 2009 suicide bombing of a South Korean tour group, followed a few days later by a second on the grieving relatives and investigators newly arrived from Korea to sort matters out. ${ }^{32}$ Most attacks occurred inside Yemen, but there were also several attempts to strike outside Yemen. ${ }^{33}$

Key to such operations was AQAP bombmaker Ibrahim al-Asiri, whose unwavering dedication to the group is perhaps best exemplified by his construction of a suicide bomb to insert in the rectum of his own brother in 2009. He succeeded in blowing his brother to pieces, but the target of the bomb, Saudi Prince Muhammad bin Nayif, was reportedly unharmed. Al-Asiri is also thought to have been the mastermind behind the underwear bomb that an AQAP-trained Nigerian man tried to detonate in a plane over Detroit on Christmas Day 2009, as well as two bombs hidden in printer cartridges and found on cargo planes in $2010 .{ }^{34}$

AQAP has also been able to inspire international attacks without the need for direct operational links. Online sermons by Yemeni-American AQAP ideologue Anwar al-Awlaqi, who was killed in a U.S. drone strike in 2011, and AQAP's English-language magazine Inspire have been linked to numerous international acts of terrorism. These include the Boston Marathon bombings in 2013, the Charlie Hebdo massacre in Paris in 2015, and the shooting at a naval base in Pensacola, Florida, in 2019. Such attacks highlight the enduring ability of AQAP's figureheads to inspire aspiring militants long after their own deaths. ${ }^{35}$

Lone wolf attacks in the West continue to be incited through bulky, if now highly infrequent, issues of Inspire. This has been supplemented since 2016 with a series of occasional Inspire Guides that offer brief analysis of the pros and cons of various terrorist attacks in the West, including the Orlando gun attack in 2016, the Nice truck massacre in France in 2016, and the Westminster attack in the United Kingdom in 2017.

\section{AQAP's key objectives}

AQAP has two core goals: expelling infidels from Muslim lands and introducing an Islamic regime to rule in accordance with Sharia (Islamic law). While these goals have remained constant, AQAP's approaches to engaging local populations and achieving these objectives have been refined according to experience and prevailing conditions.

During the instability of the Arab Spring in 2011, AQAP exploited the turmoil to establish Islamic emirates in Abyan and Shabwa. AQAP held and administered territory in these southern governorates for more than a year. It established a Sharia court and enthusiastically implemented punishments among local populations.

Although AQAP tried to undertake community projects, its overbearing governance style alienated local communities and tribal leaders. Local tribal militias, known as Popular Committees, formed and collaborated with the Yemeni military in eventually ousting AQAP from its governance role. AQAP learned from its mistakes during this short period of rule in 2011-2012. When the next governance opportunity presented itself in 2015-2016, it revised its approach.

AQAP's influence and power peaked after a Saudi-led coalition of nine Sunni Muslim countries-supported by the United States and United Kingdom-entered the Yemen conflict to restore the internationally recognized government of President Hadi in March 2015. The security and governance vacuum created by the war allowed AQAP to gain strength in the eastern governorate of Hadramawt. 
As the coalition campaign began, AQAP increased its number of fighters and its war chest by staging another jailbreak, this time freeing an estimated 300 jihadis, seizing military hardware, and robbing the central bank of an estimated $\$ 100$ million. ${ }^{36}$ By April 2015 , it had established a de facto state in Hadramawt's coastal capital of Mukalla for an entire year, until United Arab Emirates special forces, with help from the United States, forced it to withdraw in April 2016. ${ }^{37}$

AQAP entrenched its position using a number of parallel strategies that were at once practical, tactical, and ideological. This combination of strategies was key to its success, since populations in Yemen's east could not simply be terrorized into submission. Tribal communities in particular are well armed and highly practiced at resisting intruders. AQAP's success did not lie in the recruitment of what might be considered fighting "members." Even at its peak, its core fighters likely numbered no more than $4,000 .{ }^{38}$ Rather, success lay in winning enough toleration that it could continue to exist, operate, and over time expand.

AQAP revised its dictatorial governance style of 2011-2012. Just as it had rebranded itself as Ansar al-Sharia (Partisans of Islamic Law) in 2011 to distance itself from any negative baggage attached to the al-Qaida label, it again rebranded in 2015. This time it chose the name Abna' Hadramawt (the Sons of Hadramawt) for more local appeal, and it struck power-sharing deals with existing local governance structures. ${ }^{39}$ It could thus share the glory with local communities when their prospects improved but also the blame if the situation deteriorated.

AQAP carefully avoided alienating tribes and local populations in areas under its influence. When AQAP accidentally killed innocent tribesmen in operations that targeted the Yemeni military, AQAP published formal apologies and negotiated with the relevant tribes to pay blood money. ${ }^{40}$ AQAP was also mindful to invoke and praise the glorious history and courage of various tribes in several statements, videos, poems, and anashid (anthems). This framed their contemporary jihad as a natural continuation of the proud struggles of their forefathers, such as those who fought to win independence from British colonialists in the 1960 s. ${ }^{41}$

AQAP regularly exploited U.S. drone strikes, airstrikes, and raids, particularly when they resulted in the deaths of women and children or the destruction of village property. Thus, U.S. lethal action, while yielding short-term successes, can also generate long-term cycles of violence because it enables AQAP to position its jihad as justifiable revenge and to frame local misfortune as part of a global battle between believers and infidels.

AQAP also courted local populations by spearheading community development projects, such as improving utility infrastructure, building roads, and renovating schools. Approximately 56\% of tweets from AQAP's governance Twitter feed during 2016 were about its hands-on development activities. In contrast to the war raging in Yemen's west, where bombs dropped by the Saudi-led coalition destroyed civilian infrastructure as well as Houthi military targets, AQAP's territory looked like a haven of stability and security. ${ }^{42}$ AQAP financed its activities through oil imports and smuggling operations along Yemen's porous eastern coastline.

It was probably the outbreak of internationalized war in 2015 that proved the biggest boon to AQAP. The jihadis increased their relevance by framing the anti-Houthi war effort as part of their program of global jihad. Widespread fear among southerners of occupation by the Houthi northerners could be slotted directly into existing jihadi narratives of sectarian battles between Sunni believers and Shia infidels. Disputes that were in essence political were manipulated to take on a new religious significance.

\section{The Islamic State in Yemen}

The Islamic State announced its expansion into Yemen on November 13, 2014, following Islamic State leader Abu Bakr al-Baghdadi's acceptance of an oath of allegiance sworn to him by "Yemen's mujahidin." ${ }^{43}$ AQAP faced some early defections of members who joined the Islamic State. Al-Baghdadi’s group 
proclaimed various Islamic State provinces around Yemen and undertook several high-profile attacks in 2015 and 2016.

Nevertheless, the Islamic State did not usurp AQAP as Yemen's primary jihadi group. On the contrary, the arrival of the Islamic State on the world stage actually worked to AQAP's advantage in two significant ways. First, it distracted international attention away from both al-Qaida and Yemen and shifted it to Iraq and Syria. Second, the Islamic State's indiscriminate brutality allowed AQAP to position itself as the "good guy." AQAP highlighted the Muslim death toll and civilian ravages wrought by the Islamic State's devastating bombing campaign in Yemen and pledged that, unlike the Islamic State, it would not target "mosques, markets and crowded places." ${ }^{4}$

At the same time, AQAP apologized for its own previous excesses, such as the storming of a military hospital in Sanaa in 2013 and the beheading of 14 soldiers in Hadramawt in 2014, which it implicitly blamed on the negative influence of Islamic State propaganda. ${ }^{45}$

The Islamic State's inability to gain traction in Yemen, particularly among the tribes, can be attributed to several factors. Unlike AQAP, the Islamic State did not produce a narrative that was culturally specific to Yemen aside from disparaging the Houthis as infidel agents of Iran. Nor did the Islamic State engage in AQAP-style community development projects in Yemen, despite its early efforts in this regard in Syria and Iraq.

The ability to form tribal alliances has been as central to al-Qaida's success as it has to the Islamic State's relative failure in Yemen. Pro-AQAP channels on the messaging application Telegram have taken pride in AQAP's readiness to engage tribes, support community projects, and work in conjunction with local structures. ${ }^{46}$ Some Islamic State fighters in Yemen defected back to AQAP and became highly critical of the irreligious, brutal, and dictatorial behavior of its leaders. ${ }^{47}$

In fact, the Islamic State never succeeded in holding territory in Yemen and became confined largely to a single front in the Qayfa region of al-Bayda Governorate. Even this front was severely dented in October 2017 when the United States bombed its two main training camps, killing dozens of Islamic State fighters. Although a new version of the Islamic State sprang to life again in the same location in 2018, it likely did so with outside help ${ }^{48}$ and failed to gain much traction among local Yemenis. ${ }^{49}$

From mid-2018 onwards, the rivalry between AQAP and the Islamic State in Yemen erupted into all-out war, and for the next two years, they focused overwhelmingly on killing each other. Additional challenges for the Islamic State included weak communications, infiltration by spies, poor leadership, factionalism, a concerted counterterrorism campaign spearheaded by the United Arab Emirates, and a dramatic uptick in U.S. drone strikes. ${ }^{50}$ By 2020, Yemen's jihadi groups were severely degraded, held no territory, and had fragmented.

\section{The Houthi insurgency}

The Houthis derive their name from their former leader Hussein al-Houthi, but they are not a homogenous tribal group. Instead, the Houthis are a conglomeration of miscellaneous political and tribal groupings from Yemen's north, whose rhetoric has acquired increasingly religious overtones. They are predominantly Zaydi, a branch of Shia Islam but one that is markedly different from Iran's "Twelver Shiism" and closer in practice to Sunni Islam. Religious conviction played an important role in the formation of Houthi identity politics. Even their political arm is known as Ansar Allah (Partisans of God). Zaydis make up over one-third of Yemen's population of 30 million. ${ }^{51}$ As of 2020, the Houthis control territory in which two thirds of Yemen's population lives. ${ }^{52}$

The Houthis' mobilization began in the late 1980s as a cultural revivalist campaign seeking to win cultural recognition for Zaydis and to end their economic and political marginalization. They were also religiously motivated by the need to push back against influence activities conducted by Saudi-backed 
Wahhabis and local Salafis. ${ }^{53}$ This campaign led to six rounds of war between the Houthis and the Yemeni government between 2004 and 2010. ${ }^{54}$ Saudi Arabia entered into direct war with the Houthis in the last of these in 2009. ${ }^{55}$

The conflict was exacerbated by the Yemeni government's initial knee-jerk response of mass arrests and collective punishment across the Zaydi population. Previously neutral tribesmen flocked to the Houthi cause. There is some evidence that President Saleh may have deployed the Republican Guard under the command of his son Ahmad to deliberately foment the Houthi insurgency to discredit General Ali Muhsin al-Ahmar, who had been tasked with putting down the insurgency. This would weaken any potential future bid by Ali Muhsin for the presidency, which Saleh had earmarked for his son Ahmad. ${ }^{56}$

The Houthi hostilities receded between 2011 and 2014 as the Houthis joined in the Arab Spring uprising and the subsequent National Dialogue Conference sponsored by the United Nations. ${ }^{57}$ The National Dialogue, which included 565 delegates from all around Yemen, was hailed at the time by Western governments as a successful model of transition. Ultimately, however, it failed. Crucially, the National Dialogue avoided tackling the most controversial issues relating to the future shape of Yemen and the division of power, territory, and resources ${ }^{58}$ Moreover, despite the laudable inclusion of some women and youth, the Dialogue's delegates were less representative than the Dialogue's official website implied.

The Houthis, meanwhile, had become increasingly disillusioned at a transition process led by a president born in the south, backed by their former adversaries, appointed in a sham election in which he was the sole candidate, and now extended beyond his two-year term that had been due to end in early 2014 . In September 2014, the Houthis flooded the capital and took over key buildings. The final trigger for their comprehensive takeover came in January 2015 with the tabling of a federal plan that left the Houthis without access to a seaport or oil. ${ }^{59}$ In response, the Houthis placed President Hadi under house arrest and abducted his chief of staff.

The Houthi "coup" was thus generated by domestic concerns relating to the control of resources and power rather than by ideological principles externally nurtured by Iran. As international embassies closed and United Nations staff evacuated, the Houthis continued their march south to Aden. President Hadi escaped and fled to Saudi Arabia in March 2015. ${ }^{60}$ It was at this point that Saudi Arabia led a coalition of nine states into the Yemen conflict, anticipating a swift end to the Houthi insurgency.

\section{How did Sanaa and Aden fall to the Houthis?}

The Houthis' military alliance with former President Saleh proved crucial to their success in advancing swiftly south with little initial resistance from government forces. Saleh hoped to regain the presidency that he had been forced to cede to his deputy, Hadi, in 2012. Saleh had the advantage of retaining the loyalty of many of the better-trained and equipped factions of the Yemeni military, including the Republican Guard. The Houthis, therefore, had access to both military hardware and well-trained personnel. ${ }^{61}$

There is evidence of Iran and its Lebanese proxy, Hezbollah, providing weapons and military advisors to the Houthis. This was likely not as significant at this point in the conflict as their opponents claimed, and there is little evidence of Iran supplying the Houthis with heavy weapons in the early stages of the war. ${ }^{62}$ It was not Iranian assistance that explains the Houthi success; it was the collaboration with former President Saleh.

The Yemen conflict has been framed as both a sectarian battle and a proxy war between Sunni Saudi Arabia on the side of the Hadi government and Shia Iran on the side of the Houthis. The Houthis do fit into the broad orbit of Iranian influence alongside Hezbollah, significant factions of the Iraqi government, and the Syrian regime of Bashar al-Assad. ${ }^{63}$ All profess their admiration for Shia leaders and their hatred for Israel and the United States.

But the Houthis are not a direct proxy of Iran. They will work with Iran as long as it suits them, much as they worked with Saleh as long as it achieved their objectives (they eventually murdered him in 2017) ${ }^{64}$ 
The Houthi relationship with Iran is based on pragmatism rather than command and control, but it has become increasingly ideological as the war has dragged on.

Yemen has proven a relatively cheap option for Iran. It has benefited Iran to play up its role in Yemen for several reasons related to regional power politics, but it is important to distinguish between Iran's rhetoric and its tangible activities. Iran can be linked to limited military assistance to the Houthis beginning in $2011^{65}$ and to more sophisticated military assistance beginning in late $2014{ }^{66}$

Iran, however, did not need to supply the Houthis with large quantities of expensive weaponry and training; it needed only to create the perception of doing so. This was enough to concern international audiences; please domestic hardliners; elevate Iran's standing as an important regional stakeholder; and antagonize Saudi Arabia into an expensive, unpopular, and unwinnable war. It has succeeded in damaging Saudi Arabia financially and reputationally, and it has distracted Riyadh's attention away from Syria, where it opposes the Iran-backed al-Assad regime.

Moreover, contrary to what Saudi Arabia hoped, Iran's influence in Yemen increased rather than decreased as the war escalated. Whereas in January 2017, the United Nations panel of experts on Yemen concluded there was insufficient evidence of direct large-scale supply of arms from Iran, ${ }^{67}$ a year later it reported strong indications that the Houthis had received new ballistic missile technology and drones originating in Iran.$^{68}$ Since 2020, the frequency of Houthi drone and missile attacks inside Saudi Arabia has increased dramatically ${ }^{69}$ It is unlikely that this could have occurred without significant external assistance.

Overall, the Houthi insurgency was neither the direct product of Islamic sectarianism nor simply a manifestation of the broader proxy war between Saudi Arabia and Iran.

\section{Conclusion}

It is reasonable to conclude that the rise of the Houthis' political arm Ansar Allah over the past decade and the growing regional influence of Iran have occurred in tandem rather than being inextricably linked. ${ }^{70}$ While the Houthi alliance with Iran sprang more from necessity than ideological alignment, the longer the conflict has dragged on following the internationalization of Yemen's civil war in 2015, the more vulnerable the Houthis have become to Iranian influence. This is of obvious concern to the Saudiled coalition of Sunni states fighting to restore Yemen's internationally recognized government. A war that essentially grew out of a domestic political dispute has turned into a drawn-out international power struggle with sectarian overtones using proxy forces in Yemen.

Yemen looks to be in the process of fragmenting. The north-south divide remains a potent issue. In 2017, a well-organized political body known as the Southern Transitional Council emerged in Aden, the capital of the former South Yemen, with aspirations for the south to secede. Funded by the United Arab Emirates, it recruited and trained local forces across the south. These forces have clashed multiple times with the formal Yemeni military, which holds firm to the concept of a united Yemen. Although the southern secessionists and the Hadi government signed a peace deal in Riyadh in 2019 and a power-sharing cabinet was formed in late 2020, violent clashes persist.

There are also fragile fault lines inside Yemen's former South, where significant sectors of the population oppose the notion of secession, control by Aden, or influence by the United Arab Emirates. In the eastern governorates of Hadramawt and al-Mahra in particular, regional independence movements have emerged. There is, therefore, the potential for new fronts to open in Yemen. As a result, even if a peace deal is reached in the main war between the Houthis and the Yemeni government, translating this into peace on the ground has become increasingly difficult.

There are some parallels between the respective rises of the Houthi and Sunni jihadi insurgencies in Yemen. The Houthis originally attempted to win support much as al-Qaida had done during its zenith of 2015-2016: by plugging into widespread discontent and claiming to stand against ineffective government and endemic corruption. ${ }^{71}$ Similarly, both the Houthi and the Sunni jihadi insurgencies then 
attempted to re-frame their popular appeal in religious terms that would accord with their respective sectarian narratives. ${ }^{72}$

The Houthis have characterized themselves increasingly as true Muslims battling an infidel government that collaborates with both al-Qaida and the Islamic State as agents of the United States and Israel. ${ }^{73}$ Conversely, al-Qaida fighters characterize themselves as true Muslims battling infidel Houthis who collaborate-however improbably - with both Iran and the Islamic State as agents of the United States and Israel. Finally, Yemen's Islamic State fighters characterize themselves as true Muslims battling infidel Houthis who collaborate - even more improbably — not only with Iran but also with the Hadi government and al-Qaida as agents of the United States and Israel.

While the Houthis have retained a strong position during the ongoing war, both AQAP and the Islamic State in Yemen are shadows of their former selves. At the start of the war, AQAP in particular had been able to exploit the security vacuum, humanitarian crisis, and booming smuggling economy to bolster its support, influence, and funding. The Islamic State did not fare as well as AQAP in Yemen, partly owing to its weak understanding of tribal dynamics, inability to construct locally attuned narratives, weak religious credentials, and overbearing leadership style.

Nevertheless, although the jihadi groups were by 2020 weaker than they have ever been, the ideas and motivators that underpin the Salafi-jihadi movement in Yemen persist. Moreover, while the groups may recede and move underground, they do not fully disappear. By early 2021, there are signs that AQAP may be regrouping in the south. Yemen's jihadi militancy should therefore be seen as dormant or managed rather than absent or defeated.

\section{Notes}

1 "Yemen's Saleh, 'Dancing on the Heads of Snakes'," Reuters, September 23, 2011, www.reuters.com/article/ us-yemen-saleh/newsmaker-yemens-saleh-dancing-on-the-heads-of-snakes-idUSTRE78M20X20110923.

2 A Zaydi Shia imamate ruled Yemen for hundreds of years until 1962. The imams claimed authority to rule Yemen based on being descendants of the Prophet Muhammad.

3 Noel Brehony, Yemen Divided: The Story of a Failed State in South Arabia (London: I.B. Tauris, 2011$), 3$.

4 The British, however, assisted covertly. See Duff Hart-Davis, The War That Never Was: The True Story of the Men Who Fought Britain's Most Secret Battle (London: Arrow Books, 2012).

5 Elisabeth Kendall, “The Mobilisation of Yemen's Eastern Tribes: Mahra's Self-Organisation Model," in Yemen and Search for Stability, ed. Marie-Christine Heinze (London: I.B. Tauris, 2018), 78.

6 Brehony, Yemen Divided.

7 Peter Hinchcliffe, John T. Ducker, and Maria Holt, Without Glory in Arabia (London: I.B. Tauris, 2006).

8 Stephen Day, Regionalism and Rebellion in Yemen (New York: Cambridge University Press, 2012).

9 Ibid.

10 Gregory D. Johnsen, The Last Refuge: Yemen, al-Qaeda, and the Battle for Arabia (New York: Oneworld, 2012).

11 Day, Regionalism and Rebellion in Yemen.

12 Steven Erlanger, "In Yemen, U.S. Faces Leader Who Puts Family First," New York Times, January 4, 2010, www. nytimes.com/2010/01/05/world/middleeast/05saleh.html.

13 Mohamed Sudam and Mohammed Ghobari, "Yemen in State of Emergency After Protest Massacre," Reuters, March 18, 2011, www.reuters.com/article/us-yemen/yemen-in-state-of-emergency-after-protest-massacre-idUSTRE72H2Z720110318.

14 “Top Yemen General, Ali Mohsen, Backs Opposition,” BBC, March 21, 2011, www.bbc.com/news/world-middleeast-12804552.

15 Ginny Hill, Yemen Endures (London: Hurst, 2017).

16 "Saudi Arabia Launches Air Strikes in Yemen," BBC, March 26, 2015, www.bbc.com/news/world-us-canada32061632 .

17 Jonathan Saul et al., "Iran Steps Up Support for Houthis in Yemen's War-Sources," Reuters, March 21, 2017, www.reuters.com/article/us-yemen-iran-houthis/exclusive-iran-steps-up-support-for-houthis-in-yemens-warsources-idUSKBN16S22R.

18 Andrew England and Simeon Kerr, "UAE Attacks on Yemen Reveal Fractures in Saudi-Led Coalition,” Financial Times, August 29, 2019, www.ft.com/content/48f44b08-caa5-11e9-a1f4-3669401ba76f. 
19 Mustafa Hamid and Leah Farrall, The Arabs at War in Afghanistan (London: Hurst, 2015).

20 Johnsen, The Last Refuge.

21 Formal confession of Ahmad Ibrahim al-Naggar, an Islamic Jihad leader. Cited in Montasser al-Zayyat, The Road to al-Qaeda: The Story of Bin Laden's Right-Hand Man (Biography of Ayman al-Zawahiri by his Egyptian lawyer) (London: Pluto Press, 2004; original Cairo, 2002), 56-58.

22 Laurent Bonnefoy, Yemen and the World: Beyond Security (London: Hurst, 2018), 84.

23 International Crisis Group, Yemen's Al Qaeda: Expanding the Base (Brussels: International Crisis Group, 2017).

24 Ibid., 15.

25 "Yemen: Troops Raid Militants' Hide-Out," Associated Press, June 26, 2003, www.nytimes.com/2003/06/26/ world/threats-and-responses-briefly-noted-yemen-troops-raid-militants-hide-out.html.

26 Johnsen, The Last Refuge.

27 Ibid.

28 Gregory D. Johnsen, “A Profile of AQAP’s Upper Echelon,” CTC Sentinel 5, no. 7 (2012): 6-9.

29 Ibid.

30 For a brief assessment of al-Wuhayshi's skills relative to those of his successor, Qasim al-Raymi, see Elisabeth Kendall, Death of AQAP Leader Shows the Group's Fragmentation-And Durability (Washington, DC: Washington Institute, 2020).

31 "Profile:Al-Qaedainthe ArabianPeninsula,"BBC,June 16,2015,www.bbc.com/news/world-middle-east-11483095.

32 “South Koreans Urged to Flee Yemen," BBC, March 19, 2009, http://news.bbc.co.uk/2/hi/middle_east/7952303. stm.

33 "Profile: Al-Qaeda in the Arabian Peninsula."

34 "Chief Al-Qaeda Bomb Maker 'Killed in Yemen Strike'-US Reports," BBC, August 21, 2018, www.bbc.com/ news/world-middle-east-45257631.

35 Scott Shane, "The Enduring Influence of Anwar al-Awlaki in the Age of the Islamic State," CTC Sentinel 9, no. 7 (2016): 15-19.

36 Yara Bayoumy, Noah Browning, and Mohammed Ghobari, "How Saudi Arabia's War in Yemen Has Made alQaeda Stronger-And Richer," Reuters, April 8, 2016, www.reuters.com/investigates/special-report/yemen-aqap/.

37 Phil Stewart, "Small U.S. Military Team in Yemen to Aid UAE Push on al Qaeda," Renters, May 6, 2016, www. reuters.com/article/us-usa-yemen-pentagon/small-u-s-military-team-in-yemen-to-aid-uae-push-on-al-qaedaidUSKCNOXX1ZJ.

38 Bureau of Counterterrorism and Countering Violent Extremism, Country Reports on Terrorism 2015 (Washington, DC: U.S. Department of State, 2016). Higher estimates have been reported, but there is little evidence to support them.

39 Joana Cook, "Their Fate Is Tied to Ours": Assessing AQAP Governance and Implications for Security in Yemen (London: ICSR, 2019), 19.

40 See, for example, AQAP Statement "Tawdih Hawla Qadiyat Qutla Qabilat Al Bu Bakr bin Daha wa-Ibn al-Hayj" (Clarification about the Issue of Killings of the Al Bu Bakr bin Daha Tribe and Ibn al-Hayj), October 20, 2016.

41 Elisabeth Kendall, Contemporary Jihadi Militancy in Yemen: How is the Threat Evolving? (Washington, DC: Middle East Institute, 2018), 7.

42 Specific instances of Saudi airstrikes on civilian targets can be found in: Panel of Experts on Yemen, Final Report of the Panel of Experts on Yemen (New York: United Nations Security Council, 2017), 47-48; Panel of Experts on Yemen, Final Report of the Panel of Experts on Yemen (New York: United Nations Security Council, 2018), 46-47.

43 Yasir Yosef Kuoti, "Islamic State in Yemen," Terrorism Monitor 14, no. 24 (2016).

44 "Bayan Nafy al-'Alaqa bi-Tafjirat Masajid al-Huthiyyin fi San'a" (Statement Denying Links to the Bombings of Houthi Mosques in Sanaa), Al-Qaida in the Arabian Peninsula, March 20, 2015.

45 "Al-Mu'tamar al-Suhufi al-Duwali al-Awwal, ma' al-Shaykh Nasr bin 'Ali al-Anisi” (First International Press Conference, with Sheikh Nasr bin Ali al-Anisi), al-Malahim Media, December 2014; "Ta'liq 'ala Istihdaf Wizarat alDifa' bi-San'a' li-l-Qa'id Qasim al-Raymi" (Commentary on the Targeting of the Ministry of Defense in Sanaa, by Commander Qasim al-Raymi), al-Malahim Media, December 2013.

46 For a fuller comparison of AQAP and Islamic State local engagement strategies in Yemen, see Elisabeth Kendall, "Al-Qaeda and Islamic State in Yemen: A Battle for Local Audiences," in Jihadism Transformed: Al-Qaeda and Islamic State's Global Battle of Ideas, ed. Simon Staffell and Akil Awan (London: Hurst, 2016), 103-108.

47 Elisabeth Kendall, "The Failing Islamic State Within the Failed State of Yemen," Perspectives on Terrorism 13, no. 1 (2019): 80.

48 Counterterrorism Committee, Twenty-Fifth Report of the Analytical Support and Sanctions Monitoring Team (s/2020/53) (New York: United Nations Security Council, 2020), 8.

49 Elisabeth Kendall, ISIS in Yemen: Caught in a Regional Power Game (Washington, DC: Center for Global Policy, 2020). 


\section{Elisabeth Kendall}

50 Elisabeth Kendall, "Impact of the Yemen War on Militant Jihad," in Politics, Governance E Reconstruction in Yemen, ed. Marc Lynch and Stacy Philbrick Yadav (Washington, DC: POMEPS, 2018).

51 “Who Are Yemen's Houthis?” Reuters, May 20, 2015, www.reuters.com/article/idUS312582283620150520.

52 Helen Lackner and Raiman al-Hamdani, Talking to the Houthis (Berlin: European Council on Foreign Relations, 2020).

53 Several early examples of such campaigns can be found in Shelagh Weir, A Tribal Order: Politics and Law in the Mountains of Yemen (Austin: University of Texas Press, 2007); International Crisis Group, Yemen: Defusing the Saada Time Bomb (Brussels: International Crisis Group, 2009), 8.

54 A detailed history of the Houthi conflict can be found in Marieke Brandt, Tribes and Politics in Yemen: A History of the Houthi Conflict (London: Hurst, 2017).

55 Mai Yamani, "Saudi Arabia Goes to War," Guardian, November 23, 2009, www.theguardian.com/commentis free/2009/nov/23/saudi-arabia-yemen-houthi-war.

56 Additionally, Ali Muhsin was given inferior forces and denied both new hardware and support from the Republican Guard and central security services. See Sarah Phillips, Yemen and the Politics of Permanent Crisis (New York: Routledge, 2011), 93-95.

57 Gabriele von Bruck, "Saada: Ground Zero," London School of Economics (blog), June 19, 2017, https://blogs.lse. ac.uk/mec/2017/06/19/saada-ground-zero/.

58 Charles Schmitz, Yemen's National Dialogue (Washington, DC: Middle East Institute, 2014).

59 Stephen W. Day, "What's Behind Yemen's Recent Political Turmoil," Washington Post, February 23, 2015, www. washingtonpost.com/news/monkey-cage/wp/2015/02/23/whats-behind-yemens-recent-political-turmoil/.

60 "President Hadi Leaves Yemen as Saudi-Led Raid Continues," BBC, March 27, 2015, www.bbc.com/news/ world-middle-east-32078817.

61 Panel of Experts on Yemen, Final Report on Yemen (2017), 34. Note that there are also claims that Republican Guard units defected from Saleh early in the uprising, as did many military commanders. However, it is unclear whether the Yemeni military under President Hadi was able to consolidate these alleged shifts in allegiance away from Saleh.

62 Elisabeth Kendall, Iran's Fingerprints in Yemen: Real or Imagined (Washington, DC: Atlantic Council, 2017).

63 International Institute for Strategic Studies, Iran's Networks of Influence in the Middle East (London: International Institute for Strategic Studies, 2019).

64 Shuaib Almosawa and Ben Hubbard, "Yemen's Ex-President Killed as Mayhem Convulses Capital," New York Times, December 4, 2017, www.nytimes.com/2017/12/04/world/middleeast/saleh-yemen-houthis.html.

65 W. Andrew Terrill, Iranian Involvement in Yemen (Philadelphia: Foreign Policy Research Institute, 2014).

66 Thomas Juneau, "Iran's Policy Towards the Houthis in Yemen: A Limited Return on a Modest Investment," International Affairs 92, no. 3 (2016): 647-663.

67 Panel of Experts on Yemen, Final Report on Yemen (2017), 26.

68 Panel of Experts on Yemen, Final Report on Yemen (2018), 24 and 32.

69 Statement by the Acting UK Deputy Permanent Representative to the United Nations, United Nations Security Council, November 11, 2020.

70 Emile Hokayem and David Roberts, “The War in Yemen,” Survival 58, no. 6 (2016-2017): 157-186.

71 In 2016, Transparency International's Corruption Perceptions Index ranked Yemen 170 out of 176 countries.

72 For a brief account of AQAP and Islamic State-Yemen sectarian narratives, see Kendall, "Al-Qaeda and Islamic State in Yemen."

73 There is some evidence that the Houthis, or a faction within them, may themselves have collaborated with the Islamic State in Yemen. See Kendall, ISIS in Yemen. 